\title{
The role of progesterone and conceptus-derived factors in uterine biology during early pregnancy in ruminants ${ }^{1}$
}

\author{
Thomas E. Spencer, ${ }^{2}{ }^{2}$ Niamh Forde, $†$ and Patrick Lonergan $\ddagger$ \\ ${ }^{*}$ Division of Animal Sciences, University of Missouri, Columbia 65211 \\ †Division of Reproduction and Early Development, Leeds Institute of Cardiovascular and Molecular Medicine, University of Leeds, \\ Clarendon Way, Leeds, LS2 9JT, UK \\ ¥School of Agriculture and Food Science, Belfield, Dublin 4, Ireland
}

\section{ABSTRACT}

This review integrates established and new information on the role of progesterone, interferon tau (IFNT), and prostaglandins in uterine biology of ruminants. Establishment of pregnancy in ruminants encompasses growth of the posthatching blastocyst, elongation of the conceptus (embryo and extraembryonic membranes), and suppression of the endometrial luteolytic mechanism to maintain progesterone production by the ovary. Conceptus elongation involves exponential increases in length of the trophectoderm for pregnancy recognition signaling, implantation, and establishment of pregnancy. Pregnancy recognition signaling is accomplished by IFNT from the trophectoderm that has a paracrine antiluteolytic effect to inhibit upregulation of oxytocin receptors in the endometrial epithelia, thereby inhibiting production of luteolytic $\mathrm{PGF}_{2 \alpha}$ pulses by the uterus. Survival and growth of the preimplantation blastocyst and elongating conceptus clearly requires embryotrophic factors (AA, carbohydrates, proteins, lipids, and other substances) in the uterine lumen. Individual, interactive, and coordinated actions of progesterone, IFNT, and prostaglandins regulate expression of elongation- and implantation-related genes in the endometrial epithelia that, in turn alter the uterine luminal histotroph and govern conceptus survival and growth. An increased knowledge of progesterone biology and conceptus-endometrial interactions is necessary to understand and elucidate the causes of pregnancy loss and provide a basis for new strategies to improve pregnancy outcome and reproductive efficiency in ruminants.

Key words: progesterone, interferon, prostaglandin, uterus, pregnancy

Received July 6, 2015.

Accepted August 3, 2015.

${ }^{1}$ Presented as part of the Progesterone as an Endocrine Regulator Symposium at the ADSA-ASAS Joint Annual Meeting, Orlando, Florida, July 2015.

${ }^{2}$ Corresponding author: spencerte@missouri.edu

\section{INTRODUCTION}

This review integrates established and new information on the biological role of ovarian progesterone $(\mathbf{P} 4)$, conceptus interferon tau (IFNT), and prostaglandins $(\mathbf{P G})$ in uterine biology of ruminants during early pregnancy (Spencer et al., 2008; Ulbrich et al., 2013; Lonergan and Forde, 2014; Bauersachs and Wolf, 2015). Establishment of pregnancy in domestic ruminants begins at the conceptus (embryo or fetus and associated extraembryonic membranes) stage and encompasses pregnancy recognition signaling, implantation, and onset of placentation (Guillomot, 1995; Spencer et al., 2007a, 2008; Hue et al., 2012). The morula-stage embryo enters the uterus on $d 4$ to 6 postmating and then forms a blastocyst that contains an inner cell mass and a blastocoele or central cavity surrounded by a single layer of trophectoderm. After hatching from the zona pellucida (d 8 to 10), the blastocyst slowly grows into an ovoid then tubular and filamentous form and is then termed a conceptus.

In sheep, the ovoid conceptus of about $1 \mathrm{~mm}$ in length on d 11 begins to elongate on d 12 and forms a filamentous conceptus of 15 to $19 \mathrm{~cm}$ or more in length by $\mathrm{d} 15$ that occupies the entire length of the uterine horn ipsilateral to the corpus luteum (CL) with extraembryonic membranes extending into the contralateral uterine horn. In cattle, the hatched blastocyst forms an ovoid conceptus between d 12 and 14 and is only about $2 \mathrm{~mm}$ in length on d 13. By d 14, the conceptus is about $6 \mathrm{~mm}$, and the elongating bovine conceptus reaches a length of about $60 \mathrm{~mm}(6 \mathrm{~cm})$ by d 16 and is $20 \mathrm{~cm}$ or more by d 19. Thus, the blastocyst or conceptus doubles in length every day between d 9 and 16 with a significant increase $(\sim 30$ fold $)$ in length between $d$ 12 and 15 (Betteridge et al., 1980; Berg et al., 2010). Conceptus elongation involves exponential increases in length and weight of the trophectoderm (Wales and Cuneo, 1989), trophectoderm cell proliferation (Wang et al., 2009), and onset of extraembryonic membrane differentiation, including gastrulation of the embryo and formation of the yolk sac and allantois that are vi- 
tal for embryonic survival and formation of a functional placenta (Guillomot, 1995; Hue et al., 2012). Successively, the elongated conceptus begins the process of central implantation and placentation around d 16 in sheep and d 19 in cattle.

Blastocyst growth into an elongated conceptus does not occur in vitro, as it requires secretions supplied by the endometrium of the uterus (Fléchon et al., 1986; Betteridge and Flechon, 1988; Gray et al., 2001b; Brandão et al., 2004; Alexopoulos et al., 2005). Uterine luminal fluid (ULF) contains embryotrophic substances, collectively termed histotroph, that drive elongation of the conceptus via effects on trophectoderm proliferation and migration as well as attachment and adhesion to the endometrial luminal epithelium (LE) (Gray et al., 2001a; Spencer et al., 2008; Bazer et al., 2010). The ULF is derived primarily from transport and synthesis and secretion of substances by the endometrial LE and glandular epithelia ( $\mathbf{G E})$, and it is a complex and rather undefined mixture of proteins, lipids, AA, sugars (glucose, fructose), ions, and exosomes or microvesicles (Bazer, 1975, 2012; Gray et al., 2001a; Burns et al., 2014). The recurrent early pregnancy loss observed in uterine gland knockout ewes established the importance of uterine epithelial-derived histotroph for support of conceptus elongation and implantation (Gray et al., 2001b, 2002; Spencer and Gray, 2006). Available evidence in sheep and cattle supports the idea that ovarian P4 induces expression of several genes, specifically in the endometrial epithelia, that are then further stimulated by factors from the conceptus (e.g., IFNT and PG) and endometrium itself (PG; Dorniak et al., 2013a; Brooks et al., 2014; Lonergan and Forde, 2014). In turn, the genes and functions regulated by these hormones and factors in the endometrial epithelia cause specific changes in the uterine histotroph that govern conceptus survival and elongation.

\section{P4 REGULATION OF ENDOMETRIAL FUNCTION AND CONCEPTUS ELONGATION}

Progesterone stimulates and maintains endometrial functions necessary for embryonic survival, conceptus growth, implantation, placentation, and development to term. A strong positive association exists between the postovulatory rise in concentrations of $\mathrm{P} 4$ and embryonic development in sheep and cattle. The effect of P4 on conceptus growth and elongation in sheep and cattle is indirectly mediated by the endometrium (Spencer et al., 2008; Bazer et al., 2010; Lonergan, 2011; Dorniak et al., 2013a; Lonergan and Forde, 2014). During the estrous cycle and pregnancy, P4 induces a set of genes in the endometrium that establish uterine receptivity, which is the physiological state of the uterus when conceptus growth and implantation is possible. The absence of a sufficiently developed conceptus to signal pregnancy recognition results in those genes being turned off as luteolysis ensues and the animal returns to estrus for another opportunity to mate. The outcome of $\mathrm{P} 4$ actions on the endometrium is modification of the composition of the ULF, including an increase in select AA, glucose, cytokines, and growth factors, for support of blastocyst and conceptus survival and growth.

\section{Sheep}

Actions of ovarian P4 on the uterus are essential for peri-implantation conceptus survival and growth in sheep (Satterfield et al., 2006). Increasing concentrations of P4 after ovulation enhance conceptus elongation in sheep (Satterfield et al., 2006), whereas lower $\mathrm{P} 4$ concentrations in the early luteal phase retard embryonic development (Nephew et al., 1991). Between d 10 and 12 after onset of estrus or mating in cyclic and pregnant ewes, $\mathrm{P} 4$ induces the expression of many conceptus elongation- and implantation-related genes in the endometrial epithelia of the uterus (Spencer et al., 2007a, 2008; Bazer et al., 2010; Dorniak et al., 2013a; Figure 1 and Table 1). The initiation of expression of those genes requires $\mathrm{P} 4$ action and is temporally associated with the loss of progesterone receptors (PGR) between d 10 and 12 in the endometrial LE and between d 12 and 14 to 16 in the GE after onset of estrus (Spencer and Bazer, 2002); however, PGR remain present in the stroma and myometrium in the ovine uterus throughout pregnancy. In the endometrial LE and superficial GE (sGE), P4 induces genes that encode secreted attachment and migration factors [galectin-15 (LGALS15) and insulin-like growth factor binding protein one (IGFBP1)], intracellular enzymes [prostaglandin $\mathrm{G} / \mathrm{H}$ synthase and cyclooxygenase 2 (PTGS2) and hydroxysteroid (11- $\beta$ ) dehydrogenase 1 (HSD11B1)], secreted proteases [cathepsin L1 (CTSL1)], secreted protease inhibitors [cystatin $\mathrm{C}($ CST3) and 6 (CST6)], a secreted candidate cell proliferation factor [gastrin releasing peptide $(G R P)]$, glucose transporters (SLC2A1, SLC2A5, SLC5A1), and a cationic AA (arginine, lysine, and ornithine) transporter (SLC7A2). In the endometrial GE, P4 induces genes that encode for a secreted candidate cell proliferation factor $(G R P)$, a glucose transporter (SLC5A11), secreted adhesion protein (secreted phosphoprotein one or SPP1), a candidate regulator of calcium or phosphate homeostasis (STC1), and a potential immunomodulatory factor (SERPINA14, also known as uterine milk proteins or uterine serpins). Many of those P4-induced genes in the epithelia are further stimulated by the actions of IFNT and $\mathrm{PG}$, resulting in changes in components of the ULF 


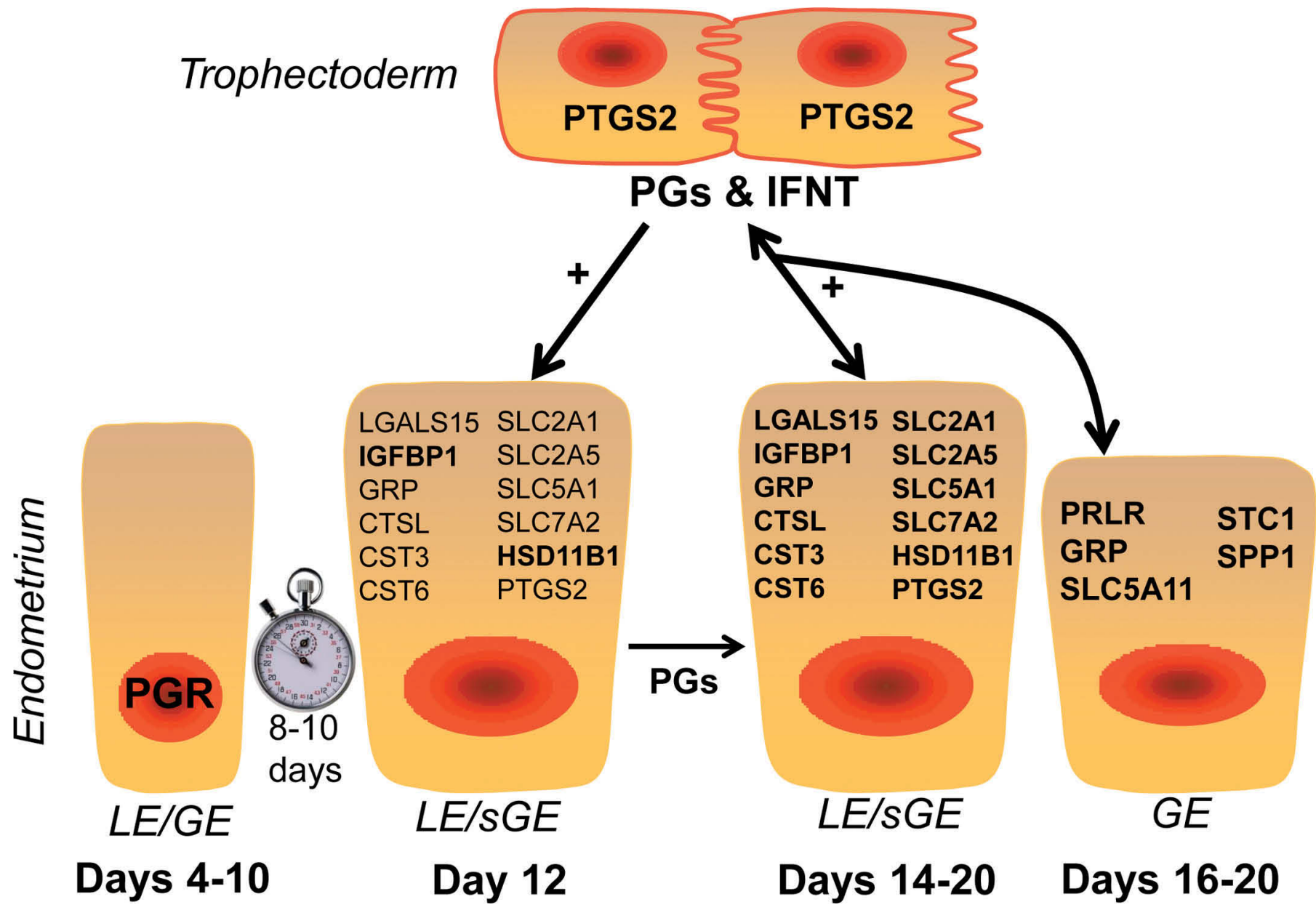

Figure 1. Schematic illustrating the effects of ovarian hormones and factors from the endometrium and conceptus trophectoderm on expression of elongation- and implantation-related genes in the endometrial epithelia of the ovine uterus during early pregnancy. Progesterone (P4) action for 8 to $10 \mathrm{~d}$ downregulates expression of the progesterone receptor (PGR). The loss of PGR is correlated with the induction of many genes in the endometrial luminal epithelium (LE) and superficial glandular epithelia (sGE), including PTGS2 involved in prostaglandin (PG) production in both cyclic and pregnant ewes. If the ewe is pregnant, the trophectoderm synthesizes and secretes PG and interferon tau (IFNT) that act on the endometrium in a cell-specific manner to upregulate the expression of many P4-induced genes that govern endometrial functions or elongation of the conceptus. $\mathrm{GE}=$ glandular epithelia. Color version available online.

histotroph that affect trophectoderm proliferation and migration (Figure 1 and Table 1).

\section{Cattle}

Due to the extensive use of AI and associated databases in cattle (compared with sheep) it is possible to examine correlations between pregnancy rates and various physiological factors in large sample sizes. Substantial evidence links circulating concentrations of $\mathrm{P} 4$ during the cycle immediately before insemination and especially in the early luteal phase of the cycle following insemination with low conception rates and greater rates of early pregnancy loss (Diskin and Morris, 2008; Salilew-Wondim et al., 2010; Lonergan, 2011). Potential mechanisms by which low concentrations of P4 during the preceding estrous cycle might reduce fertilization or embryo survival rates include effects on oocyte quality or alterations in the oviductal and uterine environment (Pursley and Martins, 2011; Rivera et al., 2011).

A combination of in vitro embryo production and in vivo embryo transfer techniques determined that $\mathrm{P} 4$ effects on conceptus development in cattle is indirect and mediated exclusively by the endometrium (Clemente et al., 2009). Addition of P4 to culture medium has no effect on blastocyst formation (Clemente et al., 2009; Larson et al., 2011) or elongation after transfer to synchronized recipients (Clemente et al., 2009). In fact, the embryo does not need to be present in the uterus during the period of $\mathrm{P} 4$ elevation to benefit from it (Clemente et al., 2009; O'Hara et al., 2014). Likewise, reducing the output of $\mathrm{P} 4$ from the CL delayed 
temporal changes in the endometrial transcriptome and compromised conceptus elongation in vivo (Forde et al., 2011a,b; O'Hara et al., 2012). Thus, available results strongly support the idea that P4 governs changes in the endometrial transcriptome (Forde et al., 2009) that govern conceptus elongation (Carter et al., 2008; Clemente et al., 2009).

Similar to findings in sheep, an adequate rise in $\mathrm{P} 4$ after ovulation drives the normal temporal changes that occur in the endometrial transcriptome of cattle that are necessary to establish uterine receptivity and promote blastocyst growth into an elongated conceptus (Lonergan and Forde, 2014). Comparisons of the endometrial transcriptome in cyclic and pregnant heifers $(\mathrm{d}$ $5,7,12$, and 13) showed no difference before pregnancy recognition (d 15 or 16; Forde et al., 2011b; Bauersachs et al., 2012). The major changes required to drive conceptus elongation and establish uterine receptivity to implantation occur between d 7 and 13 in response to ovarian $\mathrm{P} 4$, irrespective of whether an appropriately developed embryo or conceptus is present (Forde et al., 2009, 2010, 2011a,b, 2012b; Simmons et al., 2009; Forde and Lonergan, 2012). Similar to sheep, PGR protein is lost from the LE by d 13 and in the GE by d 16 of the estrous cycle or pregnancy in the bovine uterus, and PGR loss is associated with the down- and upregulation of genes expressed in the endometrial epithelia (Okumu et al., 2010). Global gene expression profiling studies have identified the temporal changes that occur in endome- trial gene expression in both cyclic (Forde et al., 2011a) and pregnant (Forde et al., 2009) heifers following an elevation or reduction of postovulatory $\mathrm{P} 4$ during metestrus that promotes or delays conceptus elongation, respectively (Beltman et al., 2009b; Clemente et al., 2009; Forde et al., 2011a). Expression of several genes is lost in the $\mathrm{LE}$ and GE, including PGR and a protease [alanyl (membrane) aminopeptidase $(A N P E P)]$, a lipase [lipoprotein lipase $(L P L)]$, protease [matrix metallopeptidase $2(M M P 2)]$, and immunomodulatory protein with antimicrobial activity [lactotransferrin $(\boldsymbol{L T F})$ ], between d 7 and 13 after onset of estrus or mating in cyclic and pregnant heifers (Forde and Lonergan, 2012; Lonergan and Forde, 2014). Between d 7 and 13 postestrus or postmating, genes upregulated in the LE encode a mitogen [connective tissue growth factor $(C T G F)]$ and a serine protease [protease serine 23 (PRSS23)], and in the GE encode a transport protein [retinol binding protein $4(R B P 4)$ ], a glucose transporter $(S L C 5 A 1)$, a zinc metalloendopeptidase [meprin A, B $[M E P 1 B)]$, a gene involved in extracellular matrix formation [nidogen 2 (NID2)], and a protein involved in transport and cell proliferation [fatty acid binding protein 3 (FABP3)]. Further, some genes are upregulated in both the LE and GE that encode secreted attachment and migration factors [lectin, galactoside-binding, soluble, 9 (LGALS9)] and IGFBP1, as well as an intracellular enzyme (PTGS2). Those gene expression changes in the endometrium elicit changes in the ULF

Table 1. Effects of ovarian progesterone (P4) and intrauterine infusion of interferon tau (IFNT) or prostaglandins $(\mathrm{PG})$ on elongation- and implantation-related genes expressed in the endometrial epithelia of the ovine uterus ${ }^{1}$

\begin{tabular}{|c|c|c|c|}
\hline Gene symbol & $\mathrm{P} 4$ & IFNT & $\mathrm{PG}^{2}$ \\
\hline \multicolumn{4}{|c|}{ Transport of glucose } \\
\hline SLC2A1 & $\uparrow$ & + & + \\
\hline$S L C 2 A 5$ & n.d. & n.e. & + \\
\hline SLC2A12 & n.d. & + & n.e. or + \\
\hline$S L C 5 A 1$ & $\uparrow$ & + & n.e. or + \\
\hline SLC5A11 & $\uparrow$ & + & n.e. or + \\
\hline \multicolumn{4}{|c|}{ Transport of AA } \\
\hline$S L C 1 A 5$ & n.d. & n.d. & + \\
\hline SLCYA2 & $\uparrow$ & + & n.e. \\
\hline \multicolumn{4}{|c|}{ Cell proliferation, migration, attachment } \\
\hline$G R P$ & $\uparrow$ & + & + \\
\hline$I G F B P 1$ & $\uparrow$ & + & ++ \\
\hline$L G A L S 15$ & $\uparrow$ & ++ & ++ \\
\hline$S P P 1$ & $\uparrow$ & + & n.d. \\
\hline \multicolumn{4}{|c|}{ Proteases and their inhibitors } \\
\hline CTSL1 & $\uparrow$ & ++ & n.e. or + \\
\hline CST3 & $\uparrow$ & + & n.e. or + \\
\hline CST6 & & + & n.e. \\
\hline \multicolumn{4}{|c|}{ Intracellular enzymes } \\
\hline$H S D 11 B 1$ & $\uparrow$ & + & ++ \\
\hline PTGS2 & $\uparrow$ & n.e. (+ activity) & n.e. (+ activity) \\
\hline
\end{tabular}

${ }^{1}$ Effect of hormone or factor denoted as induction $(\uparrow)$, stimulation $(+)$, no effect (n.e.), or not determined (n.d.).

${ }^{2}$ Summary data for infusion of $\mathrm{PGE}_{2}, \mathrm{PGF}_{2 \alpha}$, or $\mathrm{PGI}_{2}$ (Dorniak et al., 2011). 
histotroph that are hypothesized to support conceptus elongation (Forde and Lonergan, 2012; Forde et al., 2013, 2014; Lonergan and Forde, 2014). It is quite clear that differences in gene expression exist between the receptive endometrium of sheep and cattle, as one of the most abundant genes ( $L G A L S 15)$ induced by $\mathrm{P} 4$ and stimulated by IFNT in the endometrium of sheep is not expressed in cattle (Lewis et al., 2007); however, common markers of uterine receptivity and regulators of conceptus elongation also exist, such as PTGS2 and IGFBP1 (Simmons et al., 2009; Dorniak et al., 2012).

Clearly, increasing concentrations of P4 after ovulation boosts conceptus elongation in beef heifers, dairy cows, and sheep (Diskin and Morris, 2008; Spencer et al., 2008; Lonergan, 2011). However, supplementation of cattle with $\mathrm{P} 4$ during early pregnancy has equivocal efficacy in increasing embryonic survival (Beltman et al., 2009a; Parr et al., 2014) and is unlikely to rescue development of embryos with inherent genetic defects or gestated in high-producing dairy cows (Mann et al., 2006; Lonergan et al., 2007; Wiltbank et al., 2011). In fact, a recent meta-analysis of $\mathrm{P} 4$ supplementation during timed AI programs in dairy cows found that it only benefits cows without a CL and has no benefits if the cows are in estrus during the timed program (Bisinotto et al., 2015). A potential solution to low postovulatory concentrations of $\mathrm{P} 4$ in dairy cattle may be to enhance CL function via genetic strategies (Lonergan, 2011; Wiltbank et al., 2014).

\section{IFNT REGULATION OF ENDOMETRIAL FUNCTION AND CONCEPTUS ELONGATION}

Maternal recognition of pregnancy is the physiological process whereby the conceptus signals its presence to the maternal system and prolongs the lifespan of the ovarian CL (Bazer et al., 1991). In ruminants, IFNT is the pregnancy recognition signal secreted by the elongating conceptus that acts on the endometrium to inhibit development of the luteolytic mechanism (Spencer and Bazer, 2004; Spencer et al., 2007b; Bazer et al., 2010). The trophectoderm cells of the elongating conceptus secrete IFNT predominantly before implantation (Roberts et al., 2003). The antiluteolytic effects of IFNT inhibit transcription of the estrogen receptor $\alpha(E S R 1)$ gene in sheep and oxytocin receptor $(O X T R)$ gene in sheep and cattle, specifically in the endometrial LE. The absence of $O X T R$ in the endometrium prevents the release of luteolytic pulses of $\mathrm{PGF}_{2 \alpha}$, thereby ensuring maintenance of the CL and continued production of P4 (Thatcher et al., 1989; Spencer et al., 2007a). Although IFNT inhibits $O X T R$ expression in the LE and sGE, it does not inhibit expression of PTGS2, which is important for the generation of $\mathrm{PG}$ that are critical regulators of endometrial function and conceptus elongation during early pregnancy in sheep (Dorniak et al., 2011) and perhaps cattle (Spencer et al., 2013). In addition to antiluteolytic effects, IFNT acts in a paracrine manner on the endometrium to induce or enhance expression of IFN-stimulated genes (ISG) that are hypothesized to regulate uterine receptivity and conceptus elongation and implantation (Hansen et al., 1999, 2010; Spencer et al., 2008; Bazer et al., 2009). Recent studies in sheep provide in vivo evidence that IFNT is a critical regulator of conceptus elongation, and the embryotrophic actions of IFNT are principally mediated by the endometrium (Dorniak et al., 2013b; Brooks and Spencer, 2015).

\section{Classical Type I IFN-Stimulated Genes in the Endometrium}

Several experiments conducted with human cells, ovine endometrium, bovine endometrium, and bovine peripheral blood lymphocytes have elucidated genes induced by IFNT during pregnancy (Spencer et al., 2007a, 2008; Ott and Gifford, 2010; Forde et al., 2011b; Bauersachs et al., 2012). In cattle, comparisons of d 15 to 18 pregnant and nonpregnant or cyclic endometria revealed that the conceptus induces or upregulates a large number of classical ISG (Bauersachs et al., 2006, 2012; Forde et al., 2009, 2011b; Mansouri-Attia et al., 2009; Cerri et al., 2012; Forde and Lonergan, 2012). In sheep, ISG15 (ISG15 ubiquitin-like modifier) is expressed in LE of the ovine uterus on d 10 or 11 of the estrous cycle and pregnancy, but is not detected in the LE by d 12 to 13 of pregnancy (Johnson et al., 1999b). As the conceptus begins to elongate and secrete IFNT, ISG15 is induced in the stratum compactum stroma and GE by d 13 to 14, and expression extends to the stratum spongiosum stroma, deep glands, and myometrium as well as resident immune cells of the ovine uterus by d 15 to 16 of pregnancy (Johnson et al., 1999b, 2000). As IFNT production by the conceptus trophectoderm declines, expression of ISG in the stroma and GE also declines, but some remain abundant in endometrial stroma and GE on d 18 to 20 of pregnancy. Similar temporal and spatial alterations in ISG15 expression occur in the bovine uterus during early pregnancy (Johnson et al., 1999a; Austin et al., 2004).

In vivo studies revealed that the majority of studied classical ISG, such as major histocompatibility class I $(M H C)$ and $\beta$-2-microglobulin $(B 2 M)$, are not induced or upregulated by IFNT in endometrial LE or sGE of the ovine uterus during early pregnancy (Johnson et al., 1999b, 2001; Choi et al., 2001, 2003; Song et al., 2007). The lack of ISG induction and expression of $M H C$ and $B 2 M$ genes in endometrial LE or sGE during pregnancy 
may be a critical mechanism preventing immune rejection of the semiallogeneic conceptus (Choi et al., 2003). Of particular note, several reports indicate induction or increases in ISG in peripheral blood lymphocytes and the CL during pregnancy of sheep and cattle or in ewes receiving intrauterine injections of IFNT (Hansen et al., 2010; Ott and Gifford, 2010). Recent evidence indicates that IFNT exits the uterus to exert systemic effects that alter maternal physiology, including function of the CL (Hansen et al., 2010; Antoniazzi et al., 2013).

One challenge is to determine which of the large number of classical ISG induced by IFNT in the endometrium have a biological role in uterine receptivity and conceptus elongation and implantation, as ISG are traditionally implicated in the ability of Type I IFN to inhibit viral infection via cellular antiviral responses (Pestka, 2007). One classical ISG with reported biological effects on trophectoderm growth and adhesion in ruminants is $C X C L 10$ [chemokine (C-X-C motif) ligand 10; alias IP-10], a member of the $\mathrm{C}-\mathrm{X}-\mathrm{C}$ chemokine family that regulates multiple aspects of inflammatory and immune responses primarily through chemotactic activity toward subsets of leukocytes (Nagaoka et al., 2003a,b). Future research should determine the biological roles of other classical ISG in conceptus elongation and implantation in ruminants, particularly because IFNT has distinct embryotrophic effects mediated by the endometrium (Dorniak et al., 2013b; Brooks and Spencer, 2015).

\section{Nonclassical IFNT-Stimulated Genes in the Endometrium}

Although IFNT is the only known IFN to act as the pregnancy recognition signal, IFN appear to have a biological role in uterine receptivity, decidualization, and placental growth and development in many different mammals (Hansen et al., 1999; Bazer et al., 2009). A series of global and candidate gene studies found that IFNT stimulates expression of several elongation- and implantation-related genes in the ovine uterus that are initially induced by $\mathrm{P} 4$ (CST3, CST6, CTSL, GRP, HSD11B1, IGFBP1, LGALS15, SLC2A1, SLC2A5, $S L C 5 A 11$, and $S L C 7 A 2)$ in the endometrial epithelia (Spencer et al., 2007a, 2008; Figure 1 and Table 1). None of those genes are classical ISG, and thus are referred to as nonclassical ISG. Indeed, IFNT stimulation of many nonclassical ISG requires induction by $\mathrm{P} 4$ and loss of PGR in the epithelia. Importantly, many of the nonclassical ISG identified to date encode factors that have actions on the trophectoderm (proliferation, migration, attachment and adhesion, nutrient transport) important for conceptus elongation (Table 1). For example, knockdown of an AA transporter (SLC7A1) in the conceptus trophectoderm (Wang et al., 2014) and inhibition of HSD11B1 activity in utero or in the conceptus trophectoderm compromised conceptus elongation in sheep (Dorniak et al., 2013b; Brooks et al., 2015a). The effects of IFNT in the bovine endometrium are not as well understood in terms of nonclassical ISG, but recent studies have started to identify them in cattle (Forde et al., 2011b, 2012a; Bauersachs et al., 2012; Lonergan and Forde, 2014; Bauersachs and Wolf, 2015).

\section{PG REGULATION OF ENDOMETRIAL FUNCTION AND CONCEPTUS ELONGATION}

Prostaglandins regulate expression of elongation- and implantation-related genes in the endometrial epithelia of ruminants during early pregnancy and are involved in conceptus survival and elongation (Simmons et al., 2009, 2010; Dorniak et al., 2011; Spencer et al., 2013; Brooks et al., 2015b; Figure 1 and Table 1). Several decades ago, studies found that the conceptus and endometria synthesize a variety of $\mathrm{PG}\left(\mathrm{PGE}_{2}, \mathrm{PGF}_{2 \alpha}\right.$, $\mathrm{PGI}_{2}, \mathrm{PGD}_{2}$ ) during early pregnancy in both sheep and cattle (Lewis et al., 1982; Lewis and Waterman, 1983, 1985; Lewis, 1989; Charpigny et al., 1997a,b). The endometrium produces and the uterine lumen contains substantially more PG during early pregnancy than during the estrous cycle (Ellinwood et al., 1979; Marcus, 1981; Ulbrich et al., 2009). The dominant cyclooxygenase expressed in both the endometrium and trophectoderm of the elongating conceptus is PTGS2 (Charpigny et al., 1997a,b). Although the antiluteolytic effects of IFNT are to inhibit expression of the OXTR in the endometrial LE and sGE of early pregnant ewes, IFNT does not impede upregulation of PTGS2, a ratelimiting enzyme in PG synthesis (Charpigny et al., 1997b; Kim et al., 2003). As illustrated in Figure 1, PTGS2 expression appears between d 10 and 12 postestrus or postmating in the endometrial LE and sGE in response to P4 (Charpigny et al., 1997b; Simmons et al., 2010). In sheep, PTGS2 activity in the endometrium is stimulated by IFNT, and PTGS2-derived PG were found to mediate, in part, the effects of $\mathrm{P} 4$ and IFNT on the endometrium of the ovine uterus (Dorniak et al., 2011, 2012). Similarly, PTGS2 is also not downregulated in endometria of early pregnant cattle, but rather is upregulated by IFNT (Arosh et al., 2004; Emond et al., 2004). Thus, IFNT can stimulate $\mathrm{PGE}_{2}$ production in the ruminant endometrium.

Prostaglandins have a biological role in the uterus during early pregnancy, because intrauterine infusion of meloxicam, a selective PTGS2 inhibitor, into the uterus of early pregnant sheep prevented conceptus elongation 
(Simmons et al., 2010; Dorniak et al., 2011). Similarly, pregnancy rates were substantially reduced in heifers that received meloxicam on d 15 after insemination (Erdem and Guzeloglu, 2010). Of note, expression of PTGS2 in biopsies of $\mathrm{d}-7$ bovine blastocysts is a predictor of the successful development of that blastocyst to term and delivery of a live calf (El-Sayed et al., 2006). Given that membrane and nuclear receptors for PG are present in all cell types of the ovine endometrium and conceptus during early pregnancy (Cammas et al., 2006; Dorniak et al., 2011), PTGS2-derived PG from the conceptus are likely have paracrine, autocrine, and, perhaps, intracrine effects on endometrial function and conceptus development during early pregnancy (Dorniak et al., 2013a; Figure 1 and Table 1).

In addition to effects via membrane receptors, both $\mathrm{PGI}_{2}$ and $\mathrm{PGJ}_{2}$ can activate nuclear peroxisome proliferator-activating receptors (PPAR; Desvergne and Wahli, 1999); $\mathrm{PGI}_{2}$ is a ligand for PPAR delta (PPARD), and $\mathrm{PGD}_{2}$ spontaneously forms 15-deoxy$\Delta 12,14-\mathrm{PGJ}_{2}$ within cells that is a ligand for PPAR gamma (PPARG). A recent in utero study found that knockdown of PPARG in the trophectoderm compromised conceptus elongation and caused apoptosis in the trophectoderm (Brooks et al., 2015b). In other cell types and the human placenta, PPAR alter the transport, cellular uptake, storage, and use of lipids and their derivatives (Desvergne and Wahli, 1999). The PPARG-regulated genes include $F A B P$ and FA transport proteins [FATP or SLC27A] required for lipid uptake and triacylglycerol synthesis, which is undoubtedly important in the rapidly proliferating and growing ruminant conceptus that is also secreting large amounts of PG. In cattle, the preimplantation conceptus influences endometrial FA concentrations (Meier et al., 2011), and strategic feeding of specific FA can benefit fertility and milk production in lactating dairy cows (Thatcher et al., 2011). Future research should focus on the biological roles of lipids in the uterine environment during pregnancy in ruminants.

\section{CONCLUSIONS}

Our knowledge of the complex biological and genetic mechanisms governing conceptus elongation and implantation remains limited in domestic ruminants but is essential to improve fertility and reproductive efficiency in ruminant livestock. Individual, additive, and synergistic actions of $\mathrm{P} 4$, IFNT, and PG regulate expression of elongation- and implantation-related genes in the endometrial epithelia of the uterus in ruminants. The outcome of the carefully orchestrated changes in gene expression is secretion or transport of substances (e.g., glucose, AA, proteins) from the endometrium into the uterine lumen that are embryotrophic and drive conceptus elongation via effects on trophectoderm proliferation, migration, attachment, and adhesion. Although not well understood, conceptus elongation is also likely governed by transcription factors and other factors other than IFNT and PG (Mamo et al., 2012, Forde et al., 2015). A systems biology approach is necessary to fully understand conceptus elongation and the multifactorial phenomenon of early pregnancy loss. The advent of new gene editing technologies for livestock, such as transcription activator-like effector nuclease and clustered regularly interspaced short palindromic repeats/Cas9-stimulated homology-directed repair (Tan et al., 2013), are expected to accelerate our understanding of early pregnancy biology and genetic improvements in reproductive efficiency.

\section{ACKNOWLEDGMENTS}

Support for the work of the authors described in this review paper was provided, in part, by AFRI competitive grants 2009-01722 and 2012-67015-30173 from the USDA National Institute of Food and Agriculture (Washington, DC) and grants from Science Foundation Ireland (Dublin, Ireland; 07/SRC/B1156, 10/IN.1/ B3011 and 13/IA/1983).

\section{REFERENCES}

Alexopoulos, N. I., G. Vajta, P. Maddox-Hyttel, A. J. French, and A. O. Trounson. 2005. Stereomicroscopic and histological examination of bovine embryos following extended in vitro culture. Reprod. Fertil. Dev. 17:799-808.

Antoniazzi, A. Q., B. T. Webb, J. J. Romero, R. L. Ashley, N. P. Smirnova, L. E. Henkes, R. C. Bott, J. F. Oliveira, G. D. Niswender, F. W. Bazer, and T. R. Hansen. 2013. Endocrine delivery of interferon tau protects the corpus luteum from prostaglandin F2 alphainduced luteolysis in ewes. Biol. Reprod. 88:144.

Arosh, J. A., S. K. Banu, S. Kimmins, P. Chapdelaine, L. A. Maclaren, and M. A. Fortier. 2004. Effect of interferon-tau on prostaglandin biosynthesis, transport, and signaling at the time of maternal recognition of pregnancy in cattle: evidence of polycrine actions of prostaglandin E2. Endocrinology 145:5280-5293.

Austin, K. J., A. L. Carr, J. K. Pru, C. E. Hearne, E. L. George, E. L. Belden, and T. R. Hansen. 2004. Localization of ISG15 and conjugated proteins in bovine endometrium using immunohistochemistry and electron microscopy. Endocrinology 145:967-975.

Bauersachs, S., S. E. Ulbrich, K. Gross, S. E. Schmidt, H. H. Meyer, H. Wenigerkind, M. Vermehren, F. Sinowatz, H. Blum, and E. Wolf. 2006. Embryo-induced transcriptome changes in bovine endometrium reveal species-specific and common molecular markers of uterine receptivity. Reproduction 132:319-331.

Bauersachs, S., S. E. Ulbrich, H. D. Reichenbach, M. Reichenbach, M. Buttner, H. H. Meyer, T. E. Spencer, M. Minten, G. Sax, G. Winter, and E. Wolf. 2012. Comparison of the effects of early pregnancy with human interferon, alpha 2 (IFNA2), on gene expression in bovine endometrium. Biol. Reprod. 86:46.

Bauersachs, S., and E. Wolf. 2015. Uterine responses to the preattachment embryo in domestic ungulates: recognition of pregnancy and preparation for implantation. Annu. Rev. Anim. Biosci. 3:489-511.

Bazer, F. W. 1975. Uterine protein secretions: Relationship to development of the conceptus. J. Anim. Sci. 41:1376-1382. 
Bazer, F. W., G. Song, J. Kim, D. W. Erikson, G. A. Johnson, R. C. Burghardt, H. Gao, M. Carey Satterfield, T. E. Spencer, and G. Wu. 2012. Mechanistic mammalian target of rapamycin (MTOR) cell signaling: effects of select nutrients and secreted phosphoprotein 1 on development of mammalian conceptuses. Mol. Cell. Endocrinol. 354:22-33.

Bazer, F. W., T. E. Spencer, and G. A. Johnson. 2009. Interferons and uterine receptivity. Semin. Reprod. Med. 27:90-102.

Bazer, F. W., W. W. Thatcher, P. J. Hansen, M. A. Mirando, T. L. Ott, and C. Plante. 1991. Physiological mechanisms of pregnancy recognition in ruminants. J. Reprod. Fertil. Suppl. 43:39-47.

Bazer, F. W., G. Wu, T. E. Spencer, G. A. Johnson, R. C. Burghardt, and K. Bayless. 2010. Novel pathways for implantation and establishment and maintenance of pregnancy in mammals. Mol. Hum. Reprod. 16:135-152.

Beltman, M. E., P. Lonergan, M. G. Diskin, J. F. Roche, and M. A. Crowe. 2009a. Effect of progesterone supplementation in the first week post conception on embryo survival in beef heifers. Theriogenology 71:1173-1179.

Beltman, M. E., J. F. Roche, P. Lonergan, N. Forde, and M. A. Crowe. 2009b. Evaluation of models to induce low progesterone during the early luteal phase in cattle. Theriogenology 72:986-992.

Berg, D. K., J. van Leeuwen, S. Beaumont, M. Berg, and P. L. Pfeffer. 2010. Embryo loss in cattle between days 7 and 16 of pregnancy. Theriogenology 73:250-260.

Betteridge, K. J., M. D. Eaglesome, G. C. Randall, and D. Mitchell. 1980. Collection, description and transfer of embryos from cattle 10-16 days after oestrus. J. Reprod. Fertil. 59:205-216.

Betteridge, K. J., and J. E. Flechon. 1988. The anatomy and physiology of pre-attachment bovine embryos. Theriogenology 29:155-187.

Bisinotto, R. S., I. J. Lean, W. W. Thatcher, and J. E. Santos. 2015. Meta-analysis of progesterone supplementation during timed artificial insemination programs in dairy cows. J. Dairy Sci. 98:24722487.

Brandão, D. O., P. Maddox-Hyttel, P. Lovendahl, R. Rumpf, D. Stringfellow, and H. Callesen. 2004. Post hatching development: a novel system for extended in vitro culture of bovine embryos. Biol. Reprod. 71:2048-2055.

Brooks, K., G. Burns, and T. E. Spencer. 2014. Conceptus elongation in ruminants: Roles of progesterone, prostaglandin, interferon tau and cortisol. J. Anim. Sci. Biotechnol. 5:53.

Brooks, K., G. Burns, and T. E. Spencer. 2015a. Biological roles of hydroxysteroid (11-Beta) dehydrogenase 1 (HSD11B1), HSD11B2, and glucocorticoid receptor (NR3C1) in sheep conceptus elongation. Biol. Reprod. 93:38.

Brooks, K., and T. E. Spencer. 2015. Biological roles of interferon tau (IFNT) and type I IFN receptors in elongation of the ovine conceptus. Biol. Reprod. 92:47.

Brooks, K. E., G. W. Burns, and T. E. Spencer. 2015b. Peroxisome proliferator activator receptor gamma (PPARG) regulates conceptus elongation in sheep. Biol. Reprod. 92:42.

Burns, G., K. Brooks, M. Wildung, R. Navakanitworakul, L. K. Christenson, and T. E. Spencer. 2014. Extracellular vesicles in luminal fluid of the ovine uterus. PLoS ONE 9:e90913.

Cammas, L., P. Reinaud, N. Bordas, O. Dubois, G. Germain, and G. Charpigny. 2006. Developmental regulation of prostacyclin synthase and prostacyclin receptors in the ovine uterus and conceptus during the peri-implantation period. Reproduction 131:917-927.

Carter, F., N. Forde, P. Duffy, M. Wade, T. Fair, M. A. Crowe, A. C. Evans, D. A. Kenny, J. F. Roche, and P. Lonergan. 2008. Effect of increasing progesterone concentration from day 3 of pregnancy on subsequent embryo survival and development in beef heifers. Reprod. Fertil. Dev. 20:368-375.

Cerri, R. L., I. M. Thompson, I. H. Kim, A. D. Ealy, P. J. Hansen, C. R. Staples, J. L. Li, J. E. Santos, and W. W. Thatcher. 2012. Effects of lactation and pregnancy on gene expression of endometrium of Holstein cows at day 17 of the estrous cycle or pregnancy. J. Dairy Sci. 95:5657-5675.

Charpigny, G., P. Reinaud, J. P. Tamby, C. Creminon, and M. Guillomot. 1997a. Cyclooxygenase-2 unlike cyclooxygenase-1 is highly expressed in ovine embryos during the implantation period. Biol. Reprod. 57:1032-1040.

Charpigny, G., P. Reinaud, J. P. Tamby, C. Creminon, J. Martal, J. Maclouf, and M. Guillomot. 1997b. Expression of cyclooxygenase- 1 and -2 in ovine endometrium during the estrous cycle and early pregnancy. Endocrinology 138:2163-2171.

Choi, Y., G. A. Johnson, R. C. Burghardt, L. R. Berghman, M. M. Joyce, K. M. Taylor, M. D. Stewart, F. W. Bazer, and T. E. Spencer. 2001. Interferon regulatory factor-two restricts expression of interferon-stimulated genes to the endometrial stroma and glandular epithelium of the ovine uterus. Biol. Reprod. 65:1038-1049.

Choi, Y., G. A. Johnson, T. E. Spencer, and F. W. Bazer. 2003. Pregnancy and interferon tau regulate MHC class I and beta-2-microglobulin expression in the ovine uterus. Biol. Reprod. 68:17031710.

Clemente, M., J. de La Fuente, T. Fair, A. Al Naib, A. Gutierrez-Adan, J. F. Roche, D. Rizos, and P. Lonergan. 2009. Progesterone and conceptus elongation in cattle: A direct effect on the embryo or an indirect effect via the endometrium? Reproduction 138:507-517.

Desvergne, B., and W. Wahli. 1999. Peroxisome proliferator-activated receptors: nuclear control of metabolism. Endocr. Rev. 20:649-688.

Diskin, M. G., and D. G. Morris. 2008. Embryonic and early foetal losses in cattle and other ruminants. Reprod. Dom. Anim. 43(Suppl. 2):260-267.

Dorniak, P., F. W. Bazer, and T. E. Spencer. 2011. Prostaglandins regulate conceptus elongation and mediate effects of interferon tau on the ovine uterine endometrium. Biol. Reprod. 84:1119-1127.

Dorniak, P., F. W. Bazer, and T. E. Spencer. 2013a. Physiology and Endocrinology Symposium: biological role of interferon tau in endometrial function and conceptus elongation. J. Anim. Sci. 91:1627-1638

Dorniak, P., F. W. Bazer, G. Wu, and T. E. Spencer. 2012. Conceptus-derived prostaglandins regulate endometrial function in sheep. Biol. Reprod. 87:9.

Dorniak, P., T. H. Welsh Jr., F. W. Bazer, and T. E. Spencer. 2013b. Cortisol and interferon tau regulation of endometrial function and conceptus development in female sheep. Endocrinology 154:931941.

El-Sayed, A., M. Hoelker, F. Rings, D. Salilew, D. Jennen, E. Tholen, M. A. Sirard, K. Schellander, and D. Tesfaye. 2006. Large-scale transcriptional analysis of bovine embryo biopsies in relation to pregnancy success after transfer to recipients. Physiol. Genomics 28:84-96.

Ellinwood, W. E., T. M. Nett, and G. D. Niswender. 1979. Maintenance of the corpus luteum of early pregnancy in the ewe. II. Prostaglandin secretion by the endometrium in vitro and in vivo. Biol. Reprod. 21:845-856.

Emond, V., L. A. MacLaren, S. Kimmins, J. A. Arosh, M. A. Fortier, and R. D. Lambert. 2004. Expression of cyclooxygenase-2 and granulocyte-macrophage colony-stimulating factor in the endometrial epithelium of the cow is up-regulated during early pregnancy and in response to intrauterine infusions of interferon-tau. Biol. Reprod. 70:54-64.

Erdem, H., and A. Guzeloglu. 2010. Effect of meloxicam treatment during early pregnancy in Holstein heifers. Reprod. Domest. Anim. 45:625-628.

Fléchon, J. E., M. Guillomot, M. Charlier, B. Flechon, and J. Martal. 1986. Experimental studies on the elongation of the ewe blastocyst. Reprod. Nutr. Dev. 26:1017-1024.

Forde, N., F. W. Bazer, T. E. Spencer, and P. Lonergan. 2015. 'Conceptualizing' the endometrium: Identification of conceptus-derived proteins during early pregnancy in cattle. Biol. Reprod. 92:156.

Forde, N., M. E. Beltman, G. B. Duffy, P. Duffy, J. P. Mehta, P. O'Gaora, J. F. Roche, P. Lonergan, and M. A. Crowe. 2011a. Changes in the endometrial transcriptome during the bovine estrous cycle: Effect of low circulating progesterone and consequences for conceptus elongation. Biol. Reprod. 84:266-278.

Forde, N., F. Carter, T. Fair, M. A. Crowe, A. C. Evans, T. E. Spencer, F. W. Bazer, R. McBride, M. P. Boland, P. O'Gaora, P. Lonergan, and J. F. Roche. 2009. Progesterone-regulated changes 
in endometrial gene expression contribute to advanced conceptus development in cattle. Biol. Reprod. 81:784-794.

Forde, N., F. Carter, T. E. Spencer, F. W. Bazer, O. Sandra, N. Mansouri-Attia, L. A. Okumu, P. A. McGettigan, J. P. Mehta, R. McBride, P. O'Gaora, J. F. Roche, and P. Lonergan. 2011b. Conceptus-induced changes in the endometrial transcriptome: How soon does the cow know she is pregnant? Biol. Reprod. 85:144-156.

Forde, N., G. B. Duffy, P. A. McGettigan, J. A. Browne, J. P. Mehta, A. K. Kelly, N. Mansouri-Attia, O. Sandra, B. J. Loftus, M. A. Crowe, T. Fair, J. F. Roche, P. Lonergan, and A. C. Evans. 2012a. Evidence for an early endometrial response to pregnancy in cattle: both dependent upon and independent of interferon tau. Physiol. Genomics 44:799-810.

Forde, N., and P. Lonergan. 2012. Transcriptomic analysis of the bovine endometrium: What is required to establish uterine receptivity to implantation in cattle? J. Reprod. Dev. 58:189-195.

Forde, N., P. A. McGettigan, J. P. Mehta, L. O'Hara, S. Mamo, F. W. Bazer, T. E. Spencer, and P. Lonergan. 2014. Proteomic analysis of uterine fluid during the pre-implantation period of pregnancy in cattle. Reproduction 147:575-587.

Forde, N., J. P. Mehta, P. A. McGettigan, S. Mamo, F. W. Bazer, T. E. Spencer, and P. Lonergan. 2013. Alterations in expression of endometrial genes coding for proteins secreted into the uterine lumen during conceptus elongation in cattle. BMC Genomics 14:321.

Forde, N., J. P. Mehta, M. Minten, M. A. Crowe, J. F. Roche, T. E. Spencer, and P. Lonergan. 2012b. Effects of low progesterone on the endometrial transcriptome in cattle. Biol. Reprod. 87:124.

Forde, N., T. E. Spencer, F. W. Bazer, G. Song, J. F. Roche, and P. Lonergan. 2010. Effect of pregnancy and progesterone concentration on expression of genes encoding for transporters or secreted proteins in the bovine endometrium. Physiol. Genomics 41:53-62.

Gray, C. A., F. F. Bartol, B. J. Tarleton, A. A. Wiley, G. A. Johnson, F. W. Bazer, and T. E. Spencer. 2001a. Developmental biology of uterine glands. Biol. Reprod. 65:1311-1323.

Gray, C. A., R. C. Burghardt, G. A. Johnson, F. W. Bazer, and T. E. Spencer. 2002. Evidence that absence of endometrial gland secretions in uterine gland knockout ewes compromises conceptus survival and elongation. Reproduction 124:289-300.

Gray, C. A., K. M. Taylor, W. S. Ramsey, J. R. Hill, F. W. Bazer, F. F. Bartol, and T. E. Spencer. 2001b. Endometrial glands are required for preimplantation conceptus elongation and survival. Biol. Reprod. 64:1608-1613.

Guillomot, M. 1995. Cellular interactions during implantation in domestic ruminants. J. Reprod. Fertil. Suppl. 49:39-51.

Hansen, T. R., K. J. Austin, D. J. Perry, J. K. Pru, M. G. Teixeira, and G. A. Johnson. 1999. Mechanism of action of interferon-tau in the uterus during early pregnancy. J. Reprod. Fertil. Suppl. 54(Suppl.):329-339.

Hansen, T. R., L. K. Henkes, R. L. Ashley, R. C. Bott, A. Q. Antoniazzi, and H. Han. 2010. Endocrine actions of interferon-tau in ruminants. Soc. Reprod. Fertil. Suppl. 67:325-340.

Hue, I., S. A. Degrelle, and N. Turenne. 2012. Conceptus elongation in cattle: Genes, models and questions. Anim. Reprod. Sci. 134:19-28.

Johnson, G. A., K. J. Austin, A. M. Collins, W. J. Murdoch, and T. R. Hansen. 1999a. Endometrial ISG17 mRNA and a related mRNA are induced by interferon-tau and localized to glandular epithelial and stromal cells from pregnant cows. Endocrine 10:243-252.

Johnson, G. A., T. E. Spencer, R. C. Burghardt, M. M. Joyce, and F. W. Bazer. 2000. Interferon-tau and progesterone regulate ubiquitin cross-reactive protein expression in the ovine uterus. Biol. Reprod. 62:622-627.

Johnson, G. A., T. E. Spencer, T. R. Hansen, K. J. Austin, R. C. Burghardt, and F. W. Bazer. 1999b. Expression of the interferon tau inducible ubiquitin cross-reactive protein in the ovine uterus. Biol. Reprod. 61:312-318.

Johnson, G. A., M. D. Stewart, C. A. Gray, Y. Choi, R. C. Burghardt, L. Y. Yu-Lee, F. W. Bazer, and T. E. Spencer. 2001. Effects of the estrous cycle, pregnancy, and interferon tau on $2^{\prime}, 5^{\prime}$-oligoadenylate synthetase expression in the ovine uterus. Biol. Reprod. 64:1392-1399.
Kim, S., Y. Choi, F. W. Bazer, and T. E. Spencer. 2003. Identification of genes in the ovine endometrium regulated by interferon tau independent of signal transducer and activator of transcription 1. Endocrinology 144:5203-5214.

Larson, J. E., R. L. Krisher, and G. C. Lamb. 2011. Effects of supplemental progesterone on the development, metabolism and blastocyst cell number of bovine embryos produced in vitro. Reprod. Fertil. Dev. 23:311-318.

Lewis, G. S. 1989. Prostaglandin secretion by the blastocyst. J. Reprod. Fertil. Suppl. 37:261-267.

Lewis, G. S., W. W. Thatcher, F. W. Bazer, and J. S. Curl. 1982 Metabolism of arachidonic acid in vitro by bovine blastocysts and endometrium. Biol. Reprod. 27:431-439.

Lewis, G. S., and R. A. Waterman. 1983. Effects of endometrium on metabolism of arachidonic acid by bovine blastocysts in vitro. Prostaglandins 25:881-889.

Lewis, G. S., and R. A. Waterman. 1985. Metabolism of arachidonic acid in vitro by ovine conceptuses recovered during early pregnancy. Prostaglandins 30:263-283.

Lewis, S. K., J. L. Farmer, R. C. Burghardt, G. R. Newton, G. A Johnson, D. L. Adelson, F. W. Bazer, and T. E. Spencer. 2007. Galectin 15 (LGALS15): A gene uniquely expressed in the uteri of sheep and goats that functions in trophoblast attachment. Biol. Reprod. 77:1027-1036.

Lonergan, P. 2011. Influence of progesterone on oocyte quality and embryo development in cows. Theriogenology 76:1594-1601.

Lonergan, P., and N. Forde. 2014. Maternal-embryo interaction leading up to the initiation of implantation of pregnancy in cattle. Animal 8(Suppl 1):64-69.

Lonergan, P., A. Woods, T. Fair, F. Carter, D. Rizos, F. Ward, K. Quinn, and A. Evans. 2007. Effect of embryo source and recipient progesterone environment on embryo development in cattle. Reprod. Fertil. Dev. 19:861-868.

Mamo, S., D. Rizos, and P. Lonergan. 2012. Transcriptomic changes in the bovine conceptus between the blastocyst stage and initiation of implantation. Anim. Reprod. Sci. 134:56-63.

Mann, G. E., M. D. Fray, and G. E. Lamming. 2006. Effects of time of progesterone supplementation on embryo development and interferon-tau production in the cow. Vet. J. 171:500-503.

Mansouri-Attia, N., J. Aubert, P. Reinaud, C. Giraud-Delville, G. Taghouti, L. Galio, R. E. Everts, S. Degrelle, C. Richard, I. Hue, X. Yang, X. C. Tian, H. A. Lewin, J.-P. Renard, and O. Sandra. 2009. Gene expression profiles of bovine caruncular and intercaruncular endometrium at implantation. Physiol. Genomics 39:14-27.

Marcus, G. J. 1981. Prostaglandin formation by the sheep embryo and endometrium as an indication of maternal recognition of pregnancy. Biol. Reprod. 25:56-64.

Meier, S., C. G. Walker, M. D. Mitchell, M. D. Littlejohn, and J. R. Roche. 2011. Modification of endometrial fatty acid concentrations by the pre-implantation conceptus in pasture-fed dairy cows. J. Dairy Res. 78:263-269.

Nagaoka, K., H. Nojima, F. Watanabe, K. T. Chang, R. K. Christenson, S. Sakai, and K. Imakawa. 2003a. Regulation of blastocyst migration, apposition, and initial adhesion by a chemokine, interferon gamma-inducible protein $10 \mathrm{kDa}$ (IP-10), during early gestation. J. Biol. Chem. 278:29048-29056.

Nagaoka, K., A. Sakai, H. Nojima, Y. Suda, Y. Yokomizo, K. Imakawa, S. Sakai, and R. K. Christenson. 2003b. A chemokine, interferon (IFN)-gamma-inducible protein $10 \mathrm{kDa}$, is stimulated by IFN-tau and recruits immune cells in the ovine endometrium. Biol. Reprod. 68:1413-1421.

Nephew, K. P., K. E. McClure, T. L. Ott, D. H. Dubois, F. W. Bazer, and W. F. Pope. 1991. Relationship between variation in conceptus development and differences in estrous cycle duration in ewes. Biol. Reprod. 44:536-539.

O'Hara, L., N. Forde, A. K. Kelly, and P. Lonergan. 2014. Effect of bovine blastocyst size at embryo transfer on day 7 on conceptus length on day 14: Can supplementary progesterone rescue small embryos? Theriogenology 81:1123-1128.

O'Hara, L., S. Scully, V. Maillo, A. K. Kelly, P. Duffy, F. Carter, N. Forde, D. Rizos, and P. Lonergan. 2012. Effect of follicular 
aspiration just before ovulation on corpus luteum characteristics, circulating progesterone concentrations and uterine receptivity in single-ovulating and superstimulated heifers. Reproduction 143:673-682.

Okumu, L. A., N. Forde, A. G. Fahey, E. Fitzpatrick, J. F. Roche, M. A. Crowe, and P. Lonergan. 2010. The effect of elevated progesterone and pregnancy status on mRNA expression and localisation of progesterone and oestrogen receptors in the bovine uterus. Reproduction 140:143-153.

Ott, T. L., and C. A. Gifford. 2010. Effects of early conceptus signals on circulating immune cells: lessons from domestic ruminants. Am. J. Reprod. Immunol. 64:245-254.

Parr, M. H., M. A. Crowe, P. Lonergan, A. C. Evans, D. Rizos, and M. G. Diskin. 2014. Effect of exogenous progesterone supplementation in the early luteal phase post-insemination on pregnancy per artificial insemination in Holstein-Friesian cows. Anim. Reprod. Sci. 150:7-14.

Pestka, S. 2007. The interferons: 50 years after their discovery, there is much more to learn. J. Biol. Chem. 282:20047-20051.

Pursley, J. R., and J. P. Martins. 2011. Impact of circulating concentrations of progesterone and antral age of the ovulatory follicle on fertility of high-producing lactating dairy cows. Reprod. Fertil. Dev. 24:267-271.

Rivera, F. A., L. G. Mendonca, G. Lopes Jr., J. E. Santos, R. V. Perez, M. Amstalden, A. Correa-Calderon, and R. C. Chebel. 2011. Reduced progesterone concentration during growth of the first follicular wave affects embryo quality but has no effect on embryo survival post transfer in lactating dairy cows. Reproduction 141:333-342.

Roberts, R. M., T. Ezashi, C. S. Rosenfeld, A. D. Ealy, and H. M. Kubisch. 2003. Evolution of the interferon tau genes and their promoters, and maternal-trophoblast interactions in control of their expression. Reproduction 61:239-251.

Salilew-Wondim, D., M. Holker, F. Rings, N. Ghanem, M. Ulas-Cinar, J. Peippo, E. Tholen, C. Looft, K. Schellander, and D. Tesfaye. 2010. Bovine pretransfer endometrium and embryo transcriptome fingerprints as predictors of pregnancy success after embryo transfer. Physiol. Genomics 42:201-218.

Satterfield, M. C., F. W. Bazer, and T. E. Spencer. 2006. Progesterone regulation of preimplantation conceptus growth and galectin 15 (LGALS15) in the ovine uterus. Biol. Reprod. 75:289-296.

Simmons, R. M., D. W. Erikson, J. Kim, R. C. Burghardt, F. W. Bazer, G. A. Johnson, and T. E. Spencer. 2009. Insulin-like growth factor binding protein-1 in the ruminant uterus: potential endometrial marker and regulator of conceptus elongation. Endocrinology 150:4295-4305.

Simmons, R. M., M. C. Satterfield, T. H. Welsh Jr., F. W. Bazer, and T. E. Spencer. 2010. HSD11B1, HSD11B2, PTGS2, and NR3C1 expression in the peri-implantation ovine uterus: Effects of pregnancy, progesterone, and interferon tau. Biol. Reprod. 82:35-43.

Song, G., F. W. Bazer, and T. E. Spencer. 2007. Pregnancy and interferon tau regulate RSAD2 and IFIH1 expression in the ovine uterus. Reproduction 133:285-295.

Spencer, T. E., and F. W. Bazer. 2002. Biology of progesterone action during pregnancy recognition and maintenance of pregnancy. Front. Biosci. 7:d1879-d1898.

Spencer, T. E., and F. W. Bazer. 2004. Conceptus signals for establishment and maintenance of pregnancy. Reprod. Biol. Endocrinol. $2: 49$.
Spencer, T. E., N. Forde, P. Dorniak, T. R. Hansen, J. J. Romero, and P. Lonergan. 2013. Conceptus-derived prostaglandins regulate gene expression in the endometrium prior to pregnancy recognition in ruminants. Reproduction 146:377-387.

Spencer, T. E., and C. A. Gray. 2006. Sheep uterine gland knockout (UGKO) model. Methods Mol. Med. 121:85-94.

Spencer, T. E., G. A. Johnson, F. W. Bazer, and R. C. Burghardt. 2007a. Fetal-maternal interactions during the establishment of pregnancy in ruminants. Soc. Reprod. Fertil. Suppl. 64:379-396.

Spencer, T. E., G. A. Johnson, F. W. Bazer, R. C. Burghardt, and M. Palmarini. 2007b. Pregnancy recognition and conceptus implantation in domestic ruminants: Roles of progesterone, interferons and endogenous retroviruses. Reprod. Fertil. Dev. 19:65-78.

Spencer, T. E., O. Sandra, and E. Wolf. 2008. Genes involved in conceptus-endometrial interactions in ruminants: Insights from reductionism and thoughts on holistic approaches. Reproduction 135:165-179.

Tan, W., D. F. Carlson, C. A. Lancto, J. R. Garbe, D. A. Webster, P. B. Hackett, and S. C. Fahrenkrug. 2013. Efficient nonmeiotic allele introgression in livestock using custom endonucleases. Proc. Natl. Acad. Sci. USA 110:16526-16531.

Thatcher, W., J. E. Santos, and C. R. Staples. 2011. Dietary manipulations to improve embryonic survival in cattle. Theriogenology 76:1619-1631.

Thatcher, W. W., P. J. Hansen, T. S. Gross, S. D. Helmer, C. Plante, and F. W. Bazer. 1989. Antiluteolytic effects of bovine trophoblast protein-1. J. Reprod. Fertil. Suppl. 37:91-99.

Ulbrich, S. E., A. E. Groebner, and S. Bauersachs. 2013. Transcriptional profiling to address molecular determinants of endometrial receptivity-Lessons from studies in livestock species. Methods 59:108-115.

Ulbrich, S. E., K. Schulke, A. E. Groebner, H. D. Reichenbach, C. Angioni, G. Geisslinger, and H. H. Meyer. 2009. Quantitative characterization of prostaglandins in the uterus of early pregnant cattle. Reproduction 138:371-382.

Wales, R. G., and C. L. Cuneo. 1989. Morphology and chemical analysis of the sheep conceptus from the 13th to the 19th day of pregnancy. Reprod. Fertil. Dev. 1:31-39.

Wang, J., M. Guillomot, and I. Hue. 2009. Cellular organization of the trophoblastic epithelium in elongating conceptuses of ruminants. Comptes Rendus Biol. 332:986-997.

Wang, X., J. W. Frank, D. R. Little, K. A. Dunlap, M. C. Satterfield, R. C. Burghardt, T. R. Hansen, G. Wu, and F. W. Bazer. 2014 Functional role of arginine during the peri-implantation period of pregnancy. I. Consequences of loss of function of arginine transporter SLC7A1 mRNA in ovine conceptus trophectoderm. FASEB J. 28:2852-2863.

Wiltbank, M. C., A. H. Souza, P. D. Carvalho, R. W. Bender, and A. B. Nascimento. 2011. Improving fertility to timed artificial insemination by manipulation of circulating progesterone concentrations in lactating dairy cattle. Reprod. Fertil. Dev. 24:238-243.

Wiltbank, M. C., A. H. Souza, P. D. Carvalho, A. P. Cunha, J. O. Giordano, P. M. Fricke, G. M. Baez, and M. G. Diskin. 2014 Physiological and practical effects of progesterone on reproduction in dairy cattle. Animal 8(Suppl 1):70-81. 